Vagelis Bandelas

\title{
ZURNA GEOGRAPHY IN GREECE
}

\begin{abstract}
According to the current ethno-musicological research, it is taken for granted that the music material of the so called 'folk' or 'traditional' music is not a uniform and coherent body inside national boundaries but it is composed of many different local music traditions. Each one of these traditions, with the passing of time, develops elements that give its particular character and aesthetic, orally transferred from generation to generation. The type of instruments and the way they are used are two of the basic elements that appear to differ from place to place. In our paper we will focus on the types of zurna (double reed wind instrument) used today in many different areas in Greece, shaping a kind of 'zurna geography'. Besides the long zurna (kaba zurna) of Northern Greece - also well known in other Balkan countries - we will present: the smaller types, pipiza or karamuza, of central Greece (Pelion, Arachova, Thiva etc. and the Peloponnese), the minuscule zurnadi of the area of Messolonghi (West Greece) and the new medium sized zurna introduced by the folk musician Vagelis Psathas (1936-2012) in the area of Naousa (Greek Macedonia). In our analysis we will show the basic features of construction and playing techniques of each type and we will make a small reference to the social background of the musicians that participate in each case (photo 0.1).
\end{abstract}

Keywords: zurna, ancient aulos, double reed instruments, mehter music.

The history of zurna type instruments in the area that is Greece today goes back in the past. Many different theories had been told about the origin of them. In generally, Greek musicologists consider that present day zurna is - in a way connected with ancient Greek aulos, a wind instrument with a double reed mouthpiece, as it has been described by ancient writers and has been illustrated on ancient crafts. These models are established by archaeologists in many modern books (Schlesinger, 1970; Neubecker, 1986, 84) and also are reconstructed (photos 1, 2). During Byzantine period, information coming from different recourses is telling us two different stories: bands associated of trumpets, pipes and drums were in use from the Emperor for ritual purposes (Picken, 1975, 501). But from the other hand, we know as well that under the influence of Christian religion some popular expressions including public dances and instrument playing were not supported. This condemnation was especially focused on zurna type instruments (still called aulos). ${ }^{1}$ After the Ottoman conquest of the Byzantine Empire, from one side the effect of Christian church was constrained only to the Christian populations loosing big part of its former prestige, and from the other side, Ottomans created a new status, promoting in many cases new ways of life and cultural expression or resignifying former ones. We could suppose that some of these changes gave new options to the music instruments uses. Speaking about zurna, we know for sure that

\footnotetext{
${ }^{1}$ For an example, Vasileios the Great, an Orthodox Bishop of Kaisareia of Cappadocia, lived at 4th century, said that the melody of aulos is corrupted and brings the dancers in a 'transit', 'vackhic' situation (Koukoules, 1952, 240).
} 
the Ottoman Army until the early 19 century used big bands - known as Mehter during ceremonies or war campaigns, consisted of percussions and wind instruments, in which zurna had the main role. The zurna was also associated with the Ottoman wrestling tradition (Picken, 1975, 497). All these probably affected to the establishment of zurna in people's life and to the spread of these instruments also to different rural ethnic groups in south Balkan area. ${ }^{2}$ From the early $19^{\text {th }}$ century when the Ottoman administration started to update the army, introduced in Mehter bands new wind instruments of European origin, such as clarinet, trumpet, trombone, tuba etc. ${ }^{3}$ These instruments - especially the clarinet - slowly expanded also to the popular social life. Last two centuries in many areas of Greece, the clarinet dominated in folk music and took the place of zurna. Today the use of zurna is still extensiveat the Messolonghi region (South West Greece) and in Greek Macedonia, especially at regions of Serres, Katerini, Naousa, but decreased in Central Greece and Peloponnesus. There is also a bit thin use at Greek Thrace from the Muslim minority.

Peloponnesus. The characteristics of these -30 to $34 \mathrm{~cm}$ long- instruments are: the rather thin air pipe (bore), and the boldly conical and open bell, the diagram of which stands clearly outfrom the rest body. The most common combination is two zurnas and one davul (double membrane percussion). Today in Peloponnesus the zurna has a certain presence only in a few places during religion celebrations (panayir' panigiri), mainly in the northern areas. The musicians are basically of Greek Roma origin, living in villages in Patra \& Heleia areas and they are learning zurna by oral family tradition. Some of these families perform also in Messolonghi area (South West Greece), but when they play there, they use the smallest zurna that we will describe later. Usually they make the zurnas by themselves but there is not systematical and massive production. Lately they buy also instruments produced outside Greece, especially from Turkey. The Turkish models that fits more with the old 'native'ones, is the Anatolian medium sized zurnas (30 to $34 \mathrm{~cm}$ long) used in different areas from Karadeniz to Diyarbakir (photos 3, 4).

The minuscule zurna from Messolonghi \& Agrinio area. The minuscule zurna (18-23cm), known also as pipiza or karamuza in Messolonghi and Agrinio regions (South West Greece) is the smallest zurna in Greece and maybe in the Balkans. If somebody asks the local musicians about the reason of this, they say as a joke: 'in order to fit in the pocket when we go to job'. Pipiza is the model with the biggest diversity. This concerns not only the general length and shape, but also the materials it is made from. The usual material to make the body is wood, but it has been documented the use of hard plastic, bone, or even metal, especially for the construct of the bell. Zurna tradition is strong enough in this area, not only in social events (marriages etc., but basically to religion celebrations, as the fest of Saint

\footnotetext{
${ }^{2}$ Picken (1975) makes a very interesting assumption, that the combination of zurna/davul, so common in South Balkan countries, is a folk equivalent of the smallest unit of the mehter takımı, giving also the information that in some parts of Anatolia (Turkey) till today the zurna players are known as mehter (Picken, 1975, 501).

${ }^{3}$ This update is directly connected with the suppression and disbandment of the Janissaries (Yeni Çeri) at 1826 by the Sultan Mahmud II (Picken, 1975, 502; Bosworth, 2006, 626).
} 
Simon (Pentecost fest, seven Sundays after Easter). During the celebrations that last five days the band can be formed from 5 to 6 persons in order to rest each other. The musicians are entirely of Greek Roma origin living in Mesolonghi and Agrinio areas (photos 5, 6, 7, 8).

Central Greece (Thiva, Karpenisi, Arachova). Till the early $20^{\text {th }}$ century the zurna tradition was strong enough in Central Greece. The instruments used here were generally medium sized, as the previous category, but is found also a smaller model (24 to $26 \mathrm{~cm}$ ). There were two main - let's say - ethnic groups where the zurna players came from. The fist was a distinguished social category of people working also as blacksmiths and they lived in permanent houses nearby cities and villages at Livadia, Karpenisiand other areas. Probably of Roma origin, they usually self-identified as Egyptians, but for the rest people they were just gypsies. That time zurna was a 'gypsy' instrument with low prestige and usually no one else except 'gypsies' played that. After the gradual domination of clarinet in folk music -started from the late $19^{\text {th }}$ century- the use of zurna reduced dramatically, but in a strange way lost his bad rumor and people of no 'gypsy' background started to engage with it. Perhaps it was that period when some people from the rural Albanophone villages of the nearby Thiva area (known in Greece as Arvanites) started to play zurna. Some of them were professionals playing also clarinet. Today just a few players left, having rather an amateur relationship with all this (photo 9, 10).

Pelion mountain villages (Central-East Greece). The zurna type used in this area, although not in a standard format during ages, was -in general- close to the Central Greek model as we saw it before. About the construction, it has been documented in some cases the technique of 'partial' making of the body, of two separated parts, the air pipe and the bell. ${ }^{4}$ The new musicians some years before have started to use the zurna type of Naousa (Greek Macedonia), also a medium sized model $(36 \mathrm{~cm})$ with a little bit more vast body and bell. We will describe it right away. The most important celebration to which zurna tradition was -and still it is- connected with, is Maydes, an old ritual custom with music, dance and dramatization, holding every spring, which has been revitalized at the last decades (photo 11, 12).

The case of Naousa (Greek Macedonia). The Naousa type zurna is a very interesting 'case study' to understand that popular (folk) 'tradition' is a process and not stabilized stuff. Before 1950 in Naousa area it was in extended use the big sized kaba zurna. About 1950, Vagelis Psathas, a young child descended from a family of popular musicians, introduced a smaller instrument brought somewhere from Greek Thrace or Turkey. By the time he changed some elements of the first instrument and he created the model that is known today as Naousa zurna. It is medium sized (36$38 \mathrm{~cm}$ ) and in its general shape combines characteristics from Central Greece medium zurna and from the Turkish model of the Anatolian cura zurna, having a little bit more massive body and bell from both of them. The zurna tradition in Naousa city is strongly connected with the ritual celebration of Boules that it takes place every year during the Carnival period (photo 13,14).

\footnotetext{
${ }^{4}$ This technique is also found in instruments of Messolonghi area (West Greece).
} 
The 'kaba zurna' of Greek Macedonia. The big sized zurna (50-52cm), known as kaba zurna, is very common in many areas of Central Greek Macedonia, especially at Serres region. Most of the musicians are descended from Greek Roma populations living in the area since early Ottoman period. In some villages, as in Herakleia (Tzumaya) they are the earliest inhabitants. An important difference between 'kaba zurna' and the other smaller models is that the former can play two and more musical octaves, which cannot be done with the small ones. We could say that 'kaba zurna' is a kind of 'lingua franca' in South Balkans, considering that it is used in folk music in many countries, such as Albania, North Macedonia, Bulgaria and Turkey, with very similar techniques and in some cases playing similar tunes (photo 15,16).

\section{CONCLUSION}

Studding the contemporary presence of zurna in Greece we can see a clear diversity from place to place, concerning both the type and the way of use. A 'panhellenic' model (spread all around Greece) does not exist. Except the length, we should mention two important structural characteristics that make difference between types of zurna. The first has to do with the way that the metallic part of the mouthpiece (kaneli or boru) inserts in the main body. In this point there are two ways. In some areas the staple it is all putted in the body letting out only the reed, as in 'kaba' \& 'Naousa' type zurna and in other areas bigger part of the mouthpiece lies out, as in Peloponnesus \& Central Greece. The second fact is the profile, the outline that shows how much conical is the bell. Here are at least two recognizable types. One has an obviously conical and open bell, as we saw in Central Greece models and the other has a very slight conical bell that seems as to be a continuum of the rest body, as in kaba zurna of Greek Macedonia.

Also, we distinguish a recovery of the presence of the zurna in areas that almost vanished at the last decades of $20^{\text {th }}$ century, especially in the Central Greece Provinces. This fact empowered some people to attend to zurna construction in a more institutional way. The efforts of many local cultural associations to revitalize and promote their own traditions using the older and more 'authentic' instruments, helped to this direction. This -let's say- 'turn to the Traditions' did not prevent some musicians from preferring to buy zurnas from other countries, especially Turkey, where it exists a more massive production. Another interethnic network between Greece and other Balkan countries appears in some cases, especially in Greek Macedonia, at the old type wrestling games (güreş) during religion celebrations, where zurna and davul players from Bulgaria, North Macedonia and Turkey, perform together with the Greek musicians. It seems that in some cases preethnic boundaries in South Balkans - concerning at least music - open again, showing up pieces of the common cultural heritage. 


\section{LITERATURE}

BOSWORTH, C. E. (2004). The New Islamic Dynasties. A Chronological and Genealogical Manual. Edinburgh University Press.

NEUBECKER, A. J. (1977). Altgriechische Musik, Eine Einführung. Wissenschaftliche Bughgessellschaft, Darmstadt, BRD.

PICKEN, L. (1975). Folk Musical Instruments of Turkey. London: Oxford University Press.

SCHLESINGER, K. (1970). The Greek Aulos. $2^{\text {nd }}$ Ed. Groningen.

KOUKOULES, PH. (1952). Vie et Civilisation Byzantines. Tome V. Athenes.

\section{PHOTOS - MAP}

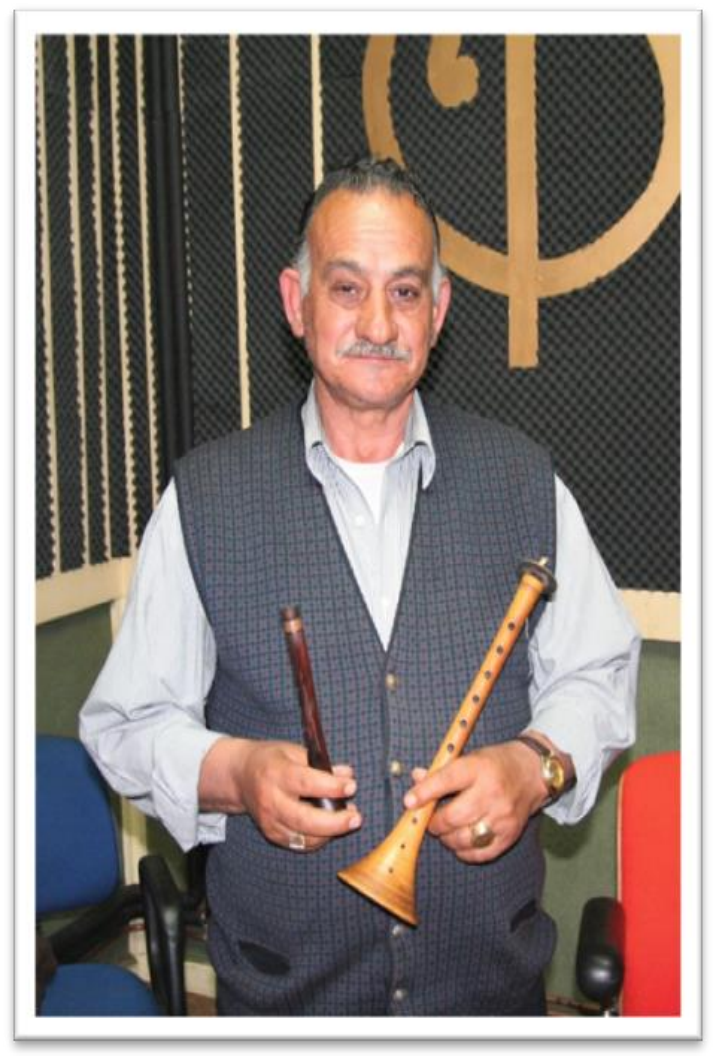

3. Dimitris Panagiotopoulos, Peloponnesus (photo by Giannis Baxevanis)

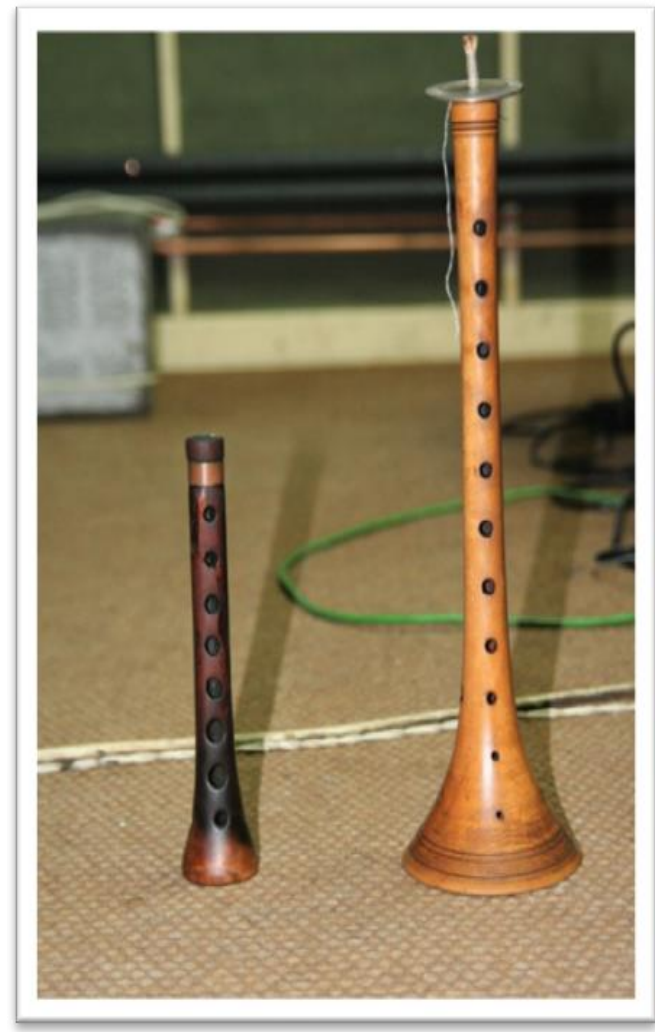

4. Two types of Peloponnesus zurna (photo by Giannis Baxevanis) 


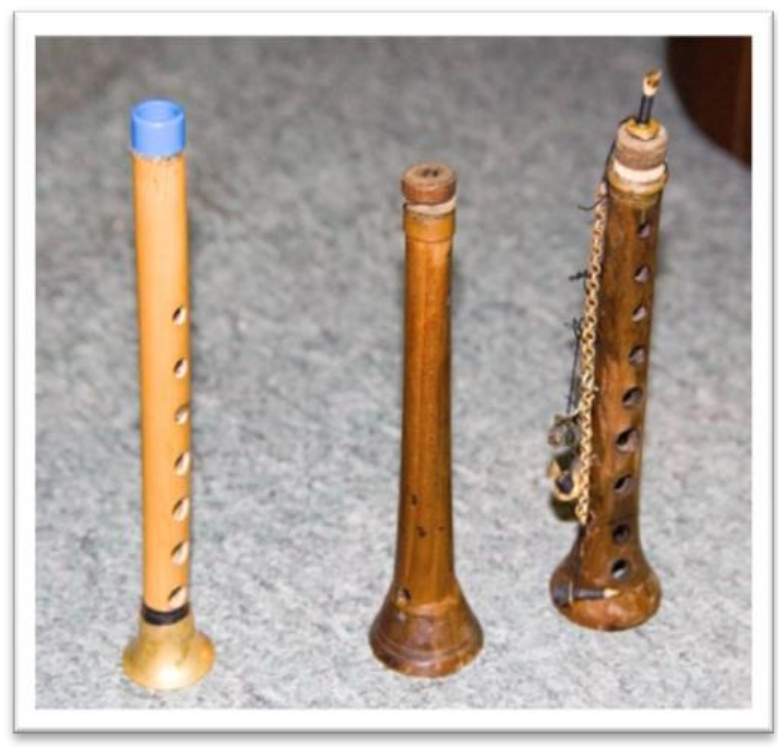

5. Zurnas from Messolonghi area (photo by Giannis Baxevanis)

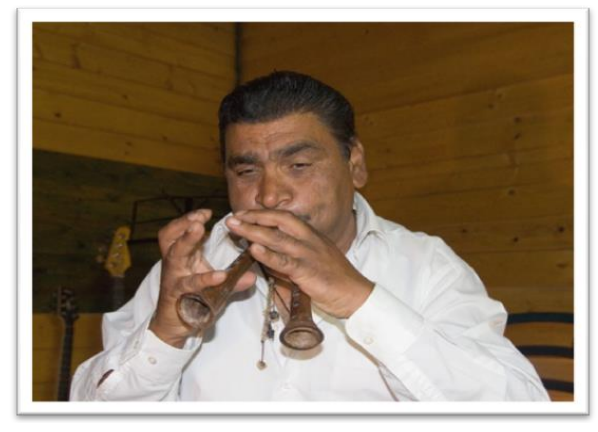

6. IliasAristopoulos,Messolonghi (photo by Giannis Baxevanis)
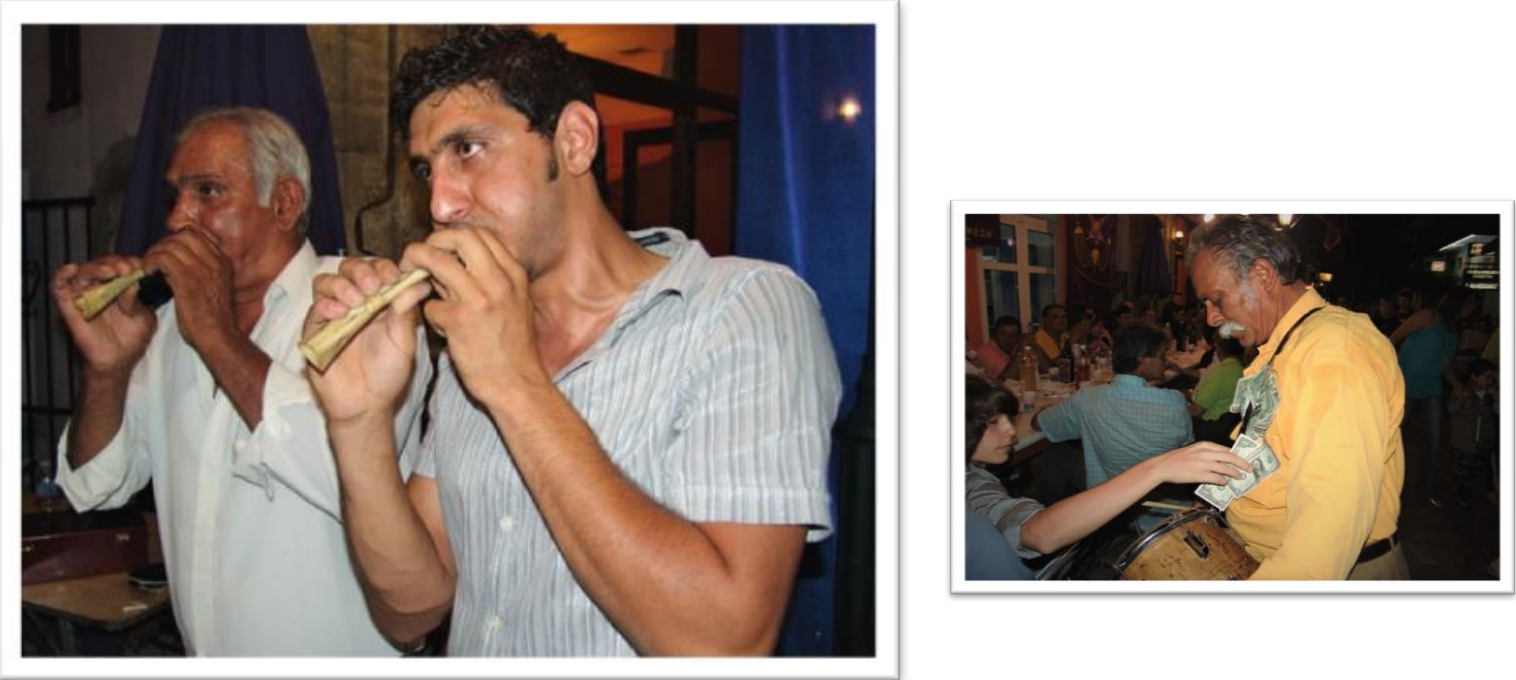

7, 8. Performing at Saint Simon Fest (Messolonghi, 2009) (photo by Giannis Magos) 


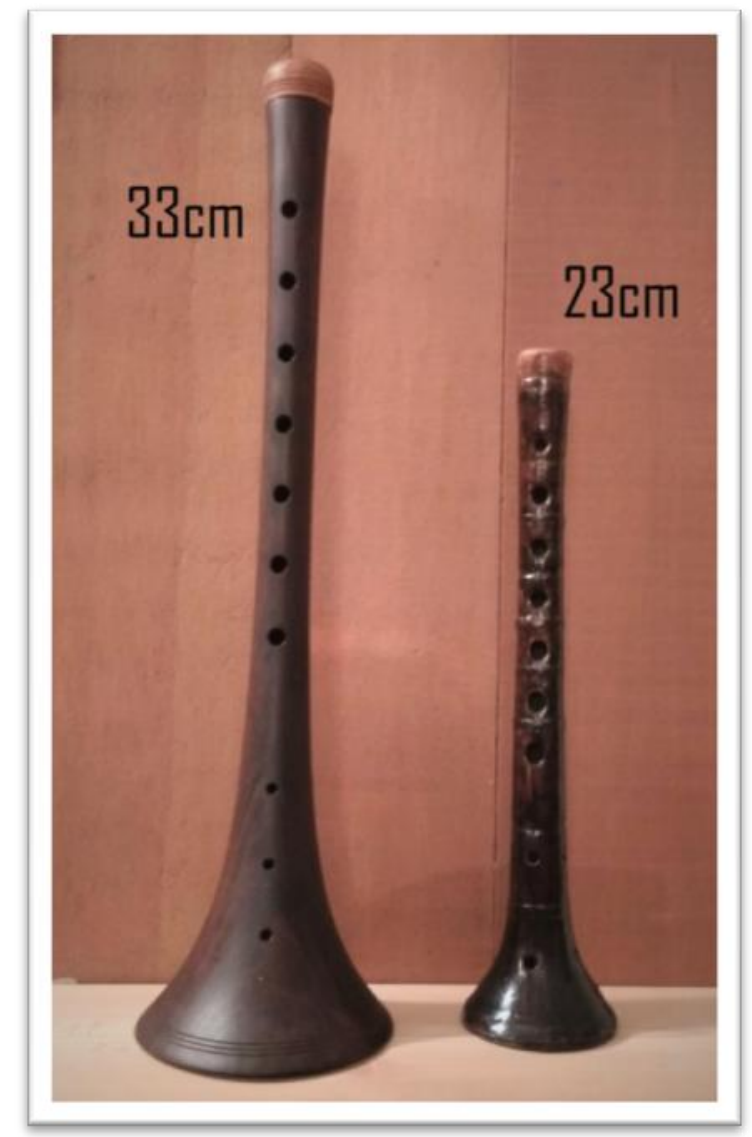

9. Two different types of Central Greece (owner Nikos Sofos, PlateesThiva)

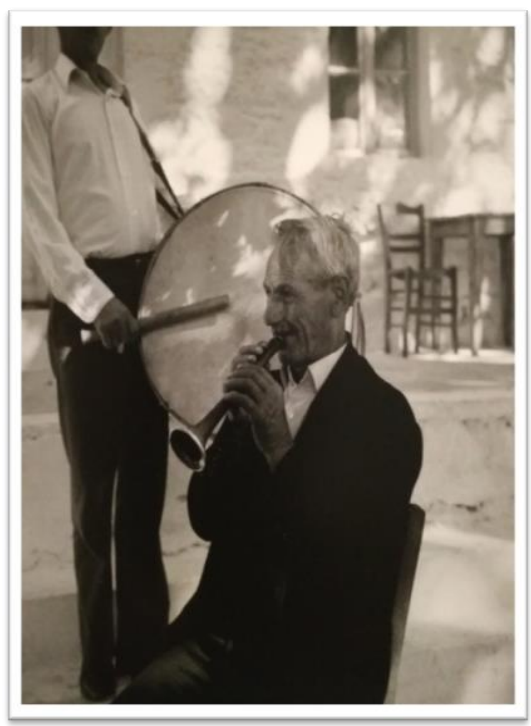

10. Arachova area, 1974 (photo by Dimitris Letsios)

Вагелис Банделас

\section{ГЕОГРАФСКАТА ЗАСТАПЕНОСТ НА ЗУРНАТА ВО ГРЦИЈА}

Резиме

Во текстот беа претставени неколку различни типови на музичкиот инструмент зурна, широко употребувана во различни предели на Грција. Разликите што се јавуваат од место до место каде таа е застапена, се согледуваат во различните типови на зурните и во различниот начин на свирење. Покрај големата зурна, таканаречена каба зурна од северниот дел на Грција (присутна и во други балкански земји како што се: Албанија, РС Македонија, Бугарија и Турција), може да се забележат и помали зурни, какви што се: „пипиза“ и „карамуза“, застапени во централниот дел на Грција (Пелион, Арахова, Теба, како и во Пелопонез). Станува збор за минијатурна зурна присутна во регионот Мисолонги (во западниот дел на Грција) и зурна со средна 
големина што Вагелис Сатас (1936-2012) ја внел како инструмент во Негуш (Егејска Македонија).

Зурната сѐ уште е присутна во некои региони, но некаде веќе се забележува нејзиното целосно исчезнување. Но, иако зурната исчезнала во последните децении на $\mathrm{XX}$ век, сепак постојат региони каде што таа повторно се појавува и се негува како дел од народната музичка традиција. 